\title{
The Expectation and Reality Gap in South Korea's Relations with China
}

\author{
HWEE-RHAK PARK*
}

This paper identifies a gap between expectation and reality in South Korea-China relations. It applies the theory of "AutonomySecurity Trade-off' and analyzes incidents such as North Korea's sinking of the Cheonan, its bombardment of the Yeonpyeong Island, and the deployment of the U.S. THAAD system in South Korea.

As a result, this paper concludes that South Korea expected more from China than it merited. Contrary to South Korean expectations, China was not ready to help South Korea on security issues. The Strategic Cooperative Partnership, which was signed in 2008 between the two countries, appeared to be just a friendly gesture, although South Korea expected cooperation in security sector.

South Korea should recognize that its partnership with China cannot replace its alliance with the U.S. It should settle for economic, social, and cultural cooperation with China and maintain security cooperation with the U.S. If South Korea reminds China of this limitation in its mutual relationship, China could also settle for its cooperation with South Korea on sectors other than security. China would therefore not intervene into South Korean security decisions as we witnessed over the deployment of the U.S. THAAD system.

Keywords: South Korea, China, South Korea-China, THAAD, Autonomy-Security

* Professor, Kookmin University, Seoul, South Korea;

E-mail: hrpark5502@hanmail.net;

DOI: 10.16934/isr.18.1.201706.77 


\section{INTRODUCTION}

South Korea has faced strong Chinese opposition over its decision to allow the deployment of the U.S. Terminal High Altitude Area Defense (THAAD) system into its territory across three years. The system is purely a defensive one and can hardly be considered as a threat to China. It cannot reach Chinese Intercontinental Ballistic Missiles (ICBM), and the THAAD's radar is ineffective beyond $1,000 \mathrm{~km}$ from a technical standpoint. Despite explanations of the limited capabilities of the THAAD by South Korea and the U.S., the Chinese government and people have not changed their position. There seemed to be reasons, other than the capabilities of the THAAD system, motivating Chinese opposition over its deployment.

China could consider South Korea its protégé based on its recent historical experiences with the Chosun Dynasty, which was the original state prior to the division of the Korean Peninsula in 1945. China behaved as a protector of Chosun and deployed its large armed forces to defend Chosun from the Japanese invasion in 1592. Chosun became loyal to China and even asked for Chinese approval when it had to designate a new king. Chosun even became an official client state in 1636 to China until 1894, when Japan defeated China on the Korean Peninsula. China may think that South Korea decided to return to the historical loyal relationship with its signing of the "Strategic Cooperative Partnership" in 2008, and that it has the right to demand South Korean acceptance when it opposes the deployment of the THAAD.

Actually, South Korea recently tried hard to improve its relationship with China, although it maintained an alliance with the U.S. The Roh Moo-hyun Administration, which started in 2003, tried to be a "balancer" between the U.S. and China, and this policy ended up establishing the "Strategic Cooperative Partnership" with China. President Park Geun-hye, who became the South Korean president in 2013, reinforced the pro-China policy and attended China's $70^{\text {th }}$ anniversary of victory in the Pacific War; she was the only national leader among U.S. allies to attend. South Korea might expect China to provide a kind of security assistance with South Korea, since it signed the "Strategic Cooperative Partnership" with China.

Unfortunately, South Korea's expectation was not met by Chinese policies in reality. China did not take any meaningful action to stop North Korea's nuclear weapons development, despite South Korea's request. China did not denounce North Korea's attack on the South Korean warship Cheonan, or on the attack against Yeonpyeong Island in 2010, contrary to South Koreas' expectation. China opposed the deployment of the U.S. THAAD, despite South Korea's explanation that the system was necessary to defend its people from a possible North Korean nuclear missile attack. 
There is an apparent huge gap between reality and South Korea's perception of the Strategic Cooperative Partnership with China. South Koreans seemed to wish the partnership to be close to an alliance and wanted to treat its relations with the U.S. and China equally. However, China seemed to view the partnership agreement as South Korea's voluntary return to the historical protégé relationship.

Based on these observations, this study examines theoretical aspects of partnership relations by modifying an alliance theory of "Autonomy-Security Trade-off," and applying it to the relations between South Korea and China. It analyzes the reality of South Korea - China relations through such cases as the Cheonan sinking, the Yeonpyeong bombardment in 2010, and the deployment of THAAD. Finally, the study recommends a few precautions that South Korea should consider for its sound relationship with China in the future.

\section{PARTNERSHIP RELATIONS AND AUTONOMY-SECURITY TRADE-OFF}

South Korea and China signed their Strategic Cooperative Partnership agreement in 2008. While the words strategic and cooperative may seem relatively empty of content, the word partnership contains meaning: possibly, a stronger relationship than common bilateral relations, although weaker than an alliance. I would like to explain the nature of partnership between nations in the modern world as follows.

\section{Alliance and Partnership}

The strongest cooperative relation among nations must be an alliance, which promises that if and when a country is attacked by other countries, its ally will regard it as an attack on itself and provide all possible assistance to defend the attacked country. In other words, this kind of relationship among nations shares victory or defeat in a war. Although some currently use the word alliance as economic alliance, value alliance, comprehensive alliance, and so on, the basic concept of alliance is a nation's promise to use military force to defend its ally. Alliance is a mechanism among nations to confront a common enemy and to pursue a common security goal.

Alliance levies serious burdens on both allies. Each country in the alliance would involve itself in an ally's dispute or war, if it decides to honor its promises. Thus, theories of entrapment and abandonment have become an agonizing theme in international relations (Snyder 1984, 466-468). That is the reason why international society invented the partnership relationship, which could mitigate the risks of an alliance such as entrapment and abandonment. The North Atlantic Treaty Organization (NATO) would be an example. NATO developed the "Partnership for 
Peace (PfP)" relationship to accept countries that were once part of the Communist bloc at the Brussels Summit in January 1994. The existing NATO members were not ready to go to war to defend those countries from the Communist bloc. They decided not to apply Article 5 of NATO treaty, which requested member countries to provide immediate security assistance to other members. The PfP countries can construct individual relations with NATO members and can become NATO members later, but cannot become a part of the alliance. There are 22 countries currently in NATO's PfP (NATO 2016).

When South Korea and China established their Strategic Cooperative Partnership in 2008, both countries did not clearly define obligations that the partner country should fulfill. However, there have been strong expectations regarding security consultations between the two countries since the partnership establishment, including the North Korean problem. China began such a partnership relation with Brazil in 1993 as an offspring of the Chinese nonalignment policy during the Cold War era. China moved to establish this relationship with about 50 countries or international organizations (Zhongping and Jing 2014, 18-19). The partnership with China may be different from the partnership in NATO, but seems to be closer than a normal international relationship, which does not have this kind of agreement. The real contents of partnership would rely on decisions, which the partner countries make in real situations.

\section{2. "Autonomy-Security Trade-off” in International Relations}

Michael F. Altfeld and James D. Morrow introduced the theory called "Autonomy-Security Trade-off" in their research on alliances in the 1980s and 1990s (Altfeld 1984; Morrow 1991). According to this theory, a small country relinquishes its autonomy to a strong and large country, which provides security assistance to the small country in return. The theory argued that an asymmetrical alliance between a small country and a large one could not continue without this trade-off. Simultaneously, an asymmetric alliance could be stronger than a symmetric alliance between similar size countries, if the trade-off is effectively maintained.

According to Michael F. Altfeld, "national security," "civilian wealth," and "freedom of action and autonomy" are interchangeable in an asymmetrical alliance (Altfeld 1984, 528). Therefore, a small country could rely on a large and strong ally's military and security assistance for its "national security" by surrendering some of its "freedom of action and autonomy" to the ally. It could strengthen its "civilian wealth" with the money it saved from its national security sector through dependence on its strong ally. The large and strong ally could also benefit from the trade-off by making the most of the small country's relinquished autonomy such as stationing its forces in the small ally's territory with full freedom and less cost, smooth coordination of foreign policies with its ally, and requesting the 
deployment of the ally's troops to deal with contingencies around the world. Therefore, a large and strong country and a small country would consider their alliance to be complementary, thus ensuring alliance continuity. If there is no such trade-off, then an asymmetrical alliance cannot be formed and maintained.

James D. Morrow defined autonomy as "the degree to which it [an entity] pursues desired changes in the status quo" or "states' ability to determine its own policies" (Morrow 1991, 908-909). According to Morrow, the small country in the alliance should make "a critical choice between conflicting goals of security and autonomy." He argues that "the pursuit of one exacts sacrifices on the other." (Morrow 1991, 930). As long as a small country is willing to sacrifice its ability to determine its own policies in order to receive security assistance from its strong and large ally, the "autonomy-security trade off" in an asymmetrical alliance could be beneficial to both sides. As a result, an asymmetrical alliance could last longer than a symmetrical alliance among relatively equal powers.

However, the trade-off between autonomy and security assistance is not limited to alliances. Although an alliance is officially obligated to committing a trade-off, there can be a similar trade-off in most relations between large and small countries. A large and strong country could demand that a small country accept its requests in exchange for various benefits including security assistance, although they did not agree on the alliance relationship. The trade-off becomes stronger if the relationship between the two countries develops into an alliance, but it becomes weaker if the relationship is neutral. If we classify the relationship among countries as a normal relationship, a partnership or an alliance, the trade-off becomes strongest in the alliance, modest in partnership, and weakest in a normal relationship. Morrow introduced a two-axis curve, Curve $\mathrm{C}$ in the Figure \#1, to explain the trade-off in the asymmetrical alliance. I would like to add two more curves to expand the trade-off relation to partnership and to a normal relation, as follows.

FiguRE 1. “AutonOMY-SECURITY TRADE-OFF” In INTERNATIONAL RELATIONS

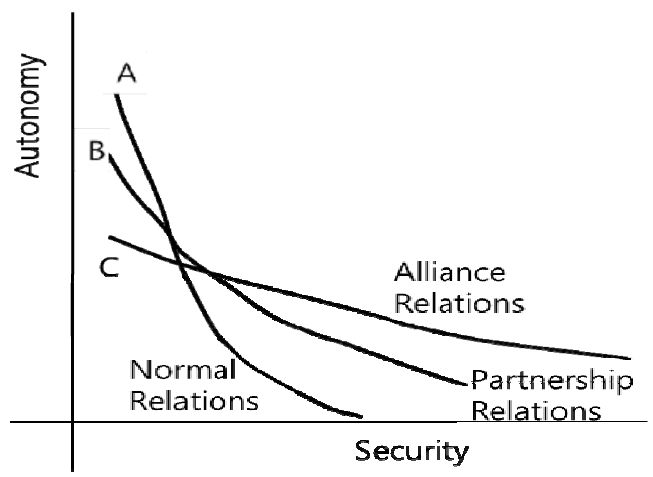

SOURCE: Park 2016, 38; Curves A and B added to the figure in Morrow 1991, 917. 
In Figure 1, Curve A stands for a normal international relationship. Curve $\mathrm{C}$ represents an alliance, and Curve B represents a closer international relationship such as a partnership. These curves could easily explain the trade-off between autonomy and security assistance of a small country regarding its relationship with a strong and large country. As Curve A shows, a small country can exercise a high degree of autonomy in return for lesser or no security assistance from a large country. In contrast, Curve $\mathrm{C}$ shows an alliance relationship in which a small country can exercise less autonomy but can expect greater security assistance from a large country. A partnership lies between alliance and a normal relationship, with moderate autonomy yielded by a small country and moderate security assistance provided by a large country. Small countries can decide respectively which relationship they want to maintain with regard to their relations with a strong and large country, but they must understand the changing nature of the trade-off based on the types of the relationship. No small country can ensure both full autonomy in terms of its sovereignty and sufficient security assistance from a strong and large country.

\section{Measuring Closeness in International Relations}

How can we measure the closeness between two countries? Evidently, an alliance constitutes the strongest international relationship, whereas an international relationship without any cooperative agreement could be the weakest. An alliance is regarded as a potential military community (Osgood 1968, 17-21). The countries in the alliance would be willing to fight a war if their ally is under attack. Then, what elements lead countries to elevate their relations to the alliance level?

If two countries are to develop a mutually cooperative relationship based on national security issues such as an alliance, they should have a common threat or common threats as a basic condition. If they have a common threat, they will endeavor to combine their defense capabilities to deal with the common threat effectively and efficiently. However, a common threat cannot guarantee close security cooperation within an alliance. Both countries must be sure they can enhance their national interests through close security cooperation with the other. Furthermore, if two countries want to establish an official security cooperation relationship such as an alliance, they should have confidence in each other regarding mutual security assistance to deal with their common threat and to enhance their common interests, especially in a time of crisis or war.

The aforementioned elements could be the minimum and common-sense conditions for close security cooperation among allied countries. Glen H. Snyder, who introduced the alliance theory of abandonment and entrapment, recommended five elements for forming an alliance: dependence, strategic interest, explicitness, shared interests, and behavior (Snyder 1984, 471-475). Among these elements, dependence is commensurate with the common threat; strategic interests and shared 
interests can be understood as mutual interests, which I explained above. Explicitness and behavior can be explained as confidence as I also explained above.

Stephen M. Walt, who conducted studies on strengthening and weakening in alliances, used three elements in his evaluation of alliance strength: changing the perception of threat, declining credibility, and domestic politics (Walt 1997, 158164). The first two elements, perception of threat and credibility, are included in the minimum and common-sense conditions for the close security cooperation among countries such as an alliance, as explained above. However, the last point, domestic politics, needs more explanation. James N. Rosenau, who introduced Linkage Theory, claimed that domestic factors influenced international decisions (Rosenau 1969, 46). This argument received much support from numerous scholars, especially those at the University of California including Robert D. Putnam. Putnam conducted a research on the interactions between international relations and domestic politics and created the Logic of Two-level Games (Evans 1993, 437). He argued that the policy makers of most countries made foreign policy decisions while calculating the ramifications of the decisions in their domestic politics. In this sense, it may be necessary to consider domestic factors together when we have to evaluate the closeness of relations among countries.

However, domestic factors may not be as crucial as other previously mentioned elements concerning international security cooperation, which periodically change from based on the situation. Most importantly, the national policy makers should try not to be overly influenced by domestic factors, which may unreasonably interfere with international agreements. For example, domestic public opinion would not accept the yielding of national autonomy to a large and strong ally even in return for indispensable security assistance by the ally. The national leader should decide to build security cooperation relations with other countries, if necessary to win the war, even though the people do not support the alliance. Therefore, I will not include domestic factors as a necessary condition for an alliance and instead cite common threats, mutual interests, and confidence as key elements in assessing the strength of relations among nations.

To begin with, common threats are the traditional and most fundamental condition for alliances in international politics. When two countries confront the same threat, they definitely try to establish a cooperative security relationship or an alliance to defend themselves effectively and efficiently. The degree of their security cooperation depends on how much these countries share the threat and contradict their enemies' interests (Snyder 1984, 471-474). If there is no common threat between two countries, they may not support each other in case of crisis or war, even though they have an official alliance treaty. On the contrary, the countries that do not have an official alliance treaty may strongly support each other, if they come to share a strong common threat.

However, a common threat alone may not be enough for two countries to 
continue an alliance or a cooperative security relationship, especially in peacetime. They should have a certain benefit to earn or expect from an alliance or close security cooperation for the continuation of an alliance or security cooperation. Because of this element, countries do not become allies just because they share a common threat. Stephen M. Waltz mentioned that the primary goal of an alliance was to integrate related countries' power in ways that enhance their mutual interests (Walt 1997, 157). An alliance or security cooperation should provide mutual benefits to the related countries if it wants to continue.

In addition to the aforementioned common threat and mutual benefit, an alliance or security cooperation needs trust or confidence between the related countries. Alliance member countries should project the impression that they will support their allies in crisis or war no matter what. They can institutionalize an alliance or cooperative security relationship based on their mutual trust or confidence. In particular, the symbol of trust or confidence is usually the capability and will of alliance members to support their allies (Walt 1997, 160). For this reason, the U.S. always emphasizes its commitments to defend its alliances and friendly countries by deploying U.S. forces and conducting various types of combined exercises.

Therefore, one should at least apply the three elements of common threat, mutual benefit and trust in order to measure the strength of an alliance or security cooperation. The real strength of relations among certain countries could be stronger than official allies and vice versa. If we apply these three elements in South KoreaChina relations, we could identify the potentiality of their mutual relations in the future.

\section{ANALYSIS OF SOUTH KOREA-CHINA RELATIONS}

\section{Background}

Because the South Korea-China relationship is asymmetrical in terms of national power, there must be a kind of trade-off between autonomy and security assistance in nature. We can find the trade-off in most of the relations between Chinese dynasties and Korean dynasties throughout history. The trade-off was conspicuous during the Chosun Dynasty, which began in 1392 and ended in 1910 with Japan's colonization. The Chosun Dynasty adopted the policy of "respect for the strong and good relations with other neighbors" for its foreign relations. It asked approval of the Chinese dynasty when it came to appointing a new king. In return, the Chinese dynasty provided security assistance for Chosun in 1592, when Japan invaded Chosun. Chosun even became a subordinate country to the Chinese dynasty, which invaded Chosun in 1636. Chinese dynasties generally maintained patron-client state relationships with Korean dynasties. 
The historical patron-client relationship between Korea and China ended with the Japanese occupation of Korea from 1910 to 1945. The U.S. happened to intervene in Korea as a result of its war against Japan in 1945 and had to settle for a divided Korea, especially the southern half of Korea, because of the Soviet Union's occupation of the northern part of the peninsula. The US had to send its troops to defend South Korea in 1950, when North Korea invaded South Korea. It even had to establish an alliance relationship as the invasion ended with the armistice agreement. As a result, South Korea seems to re-establish its historical patron-protégé relationship with the U.S. and today the relationship endures.

However, South Korea has trended toward a closer relationship with China. Several recent South Korean governments attempted to improve their relations with China and asked China to take a more active role for peace and reunification of the Korean Peninsula. The Roh Moo-hyun administration, which continued from 2003 to 2008, expressed its goal to be a balancer between China and the U.S. As an achievement of the trend, South Korea signed the "Strategic Cooperative Partnership" with China in 2008 and a Free Trade Agreement in 2014.

South Korean attempts to be closer to China eventually resulted in the weakening of its relations with the U.S., which has been a staunch ally since the end of the Korean War in 1953. South Koreans demanded the dismantlement of the Combined Forces Command (CFC) between South Korea and the U.S. by retaking operational control over its forces from the commander of CFC. There have been numerous anti-U.S. demonstrations over many issues regarding U.S. forces in Korea. South Korean President Park Geun-hye, who was inaugurated in 2013, attended the Chinese ceremony in September 2015 to commemorate the victory in the Pacific War. Some South Koreans started to believe that China would not help North Korea (30.9\%) and could even help South Korea (34.9\%) in case of war between South Korea and North Korea (Tiejun, et al. 2016, 12-13). South Korean expectations of China became high and seemed to expand to security cooperation.

However, South Korea failed to fulfill its expectations regarding security cooperation with China despite its sincere efforts to improve its relation with China. For example, China did not denounce North Korea when it sank the South Korean warship Cheonan and conducted an artillery bombardment of South Korea's Yeonpyeong Island in 2010. Neither did China comply actively with various United Nations Security Council (UNSC) sanctions to stop North Korean nuclear weapons development. It was very natural for the South Korean people to raise doubts about their new policies toward China.

\section{Examination}

Some South Koreans may believe that South Korea and China can make an 
alliance-level relationship if South Korea continues to improve its relationship with China. Will this be possible? I would like to answer this question by examining the three conditions for alliance mentioned previously: common threat, mutual benefit, and confidence.

First, a meaningful common threat that may demand close security cooperation between South Korea and China does not seem to exist. China could consider the U.S., Japan, and Russia threats or potential threats. However, the U.S. is an ally of South Korea. Russia is hardly a direct threat to South Korea, because the two countries do not even share common borders and do not have any direct adversarial history. Only Japan could be a common threat to China and South Korea, because the two countries share the experience of Japanese colonization. China has disputes with Japan over Daioyu Dao (Senkaku Island) and South Korea has difference of opinion with Japan over Dokdo. However, South Korea and Japan have engaged in friendly relations for more than 50 years since the normalization of diplomatic relations in 1965 . They have been in an indirect alliance relation through the South Korea-U.S. alliance and the U.S.-Japan alliance. Moreover, North Korea is an ally of China but an enemy of South Korea. The U.S. is a strong ally of South Korea and may be a potential enemy of China. In sum, South Korea and China can hardly have a common threat, which may compel the two countries to cooperate closely with each other in some cases.

Secondly, the mutual benefits between South Korea and China would not be small if they established an alliance relationship. Considering both countries' large armed forces, aggregation of their military forces would make them powerful. China could broaden its strategic scope toward the Pacific Ocean, if it could acquire security cooperation with South Korea. South Korea could be an outpost for defending Chinese territory against sea powers and be a dagger for attacking the U.S. and Japan in the case of war. However, the benefit that South Korea could acquire from its close security cooperation with China seems to be uncertain. China cannot send its troops to South Korea or support South Korean foreign policies unless it gives up its relations with North Korea. China can only realize significant benefits if it succeeds in making an ally of South Korea. That is why China has attempted to decouple South Korea from the U.S. Also, China may consider South Korea the weakest element in the coalition between the U.S., Japan, and South Korea (Seo 2014, 275). Cooperation between South Korea and China in the military fields would not create a synergy effect, because both countries have predominant armies and similar technological levels in terms of military weapons and equipment. The two countries can strengthen their cooperation in fields of economy, society, and culture, if they create an alliance relationship. However, these cooperative benefits could be achieved even without an alliance relationship.

Thirdly, South Korea and China do not seem to have much trust and confidence in each other. They fought against each other in the Korean War from 
1950 to 1953. They had hostile relations during the Cold War and China did not abandon communism, which South Korea vehemently opposed. The U.S., which is a staunch South Korean ally, could be a strategic rival to China. North Korea, which has been a staunch Chinese ally, is the enemy of South Korea. South Korea and China would not likely support each other if they had to sacrifice their alliances. The Chinese appears to think that a good China-South Korea relationship is not sustainable, because they should not or will not abandon North Korea (Tiejun et al. 2016, 39). South Korea will also not support China by sacrificing its alliance with the U.S. The trust level between South Korea and China cannot be sufficient enough for a relationship with close security cooperation or an alliance.

In this respect, South Korea and China do not seem to have sufficient conditions for a close security cooperation or an alliance. The two countries do not seem to have much potential for an enhanced relationship in terms of security cooperation. Although South Korea and China established the Strategic Cooperative Partnership in 2008, it is highly probable that the agreement will remain only as political rhetoric (Kim 2013, 6-7).

\section{Autonomy-Security Trade-off in the South Korea-China Relations}

The relationship between China and South Korea should be asymmetric because the former is strong and large and the latter is small. The asymmetric relationship has continued throughout their mutual history (Womack 2010, 515517). It is natural to assume that there is a sort of a trade-off between autonomy and security in South Korea-China relations. Actually, South Korea expected China's security cooperation, especially with regard to North Korea, after signing the Strategic Cooperative Partnership with China in 2008. South Korea tried to surrender some of its autonomy by weakening its alliance with the U.S. and following Chinese foreign policies, while expecting something in return from China.

However, South Korea has been frustrated with a Chinese lack of reciprocal cooperation in mitigating the North Korean threat. China did not do much to stop North Korea's nuclear ambition, and it did not try to behave as a neutral neighbor regarding North Korean military provocations. The Strategic Cooperative Partnership between South Korea and China seems to be nothing more than an ordinary relationship between two countries. South Korea expected Curve B, which stands for the partnership relation in Figure 1, Section II, with China, since its establishment of the partnership with China in 2008. However, South Korea came to recognize that its current relationship with China is nothing more than a normal international relationship as illustrated by Curve A in the same Figure 1 .

Actually, China did not make any promise to begin security cooperation with 
South Korea. China may have thought that the partnership relationship could only be an official declaration of normal relations with South Korea, which was its adversarial neighbor during the Cold War. South Korea seems to have expected too much regarding its Strategic Cooperative Partnership with China. It failed to achieve any cooperative results with China in term of military or security issues. The accurate description of the South Korea-China relation could be "Hot-onEconomy but Cold-on-Politics" (Seo 2014, 263).

Some South Koreans still expect China to help denuclearize North Korea or to support reunification of the Korean people. They want to consider China as an alternative to the U.S. for solving problems with North Korea. They tried not to offend China in order to obtain its support in dealing with North Korean problems. However, the possibility for China to fulfill such expectations seems considerably low. So far, China has made no practical effort to stop North Korean nuclear ambition despite sincere requests by South Korea and by the international community. To the contrary, China has attempted to interfere in South Korean internal affairs as demonstrated regarding the deployment of the U.S. THAAD system, as old Chinese dynasties had done to Chosun dynasty. China seems to demand that South Korea surrender some autonomy without providing security cooperation in return, unlike the "Autonomy-security Trade-off" theory. China may intend to turn South Korea into its "Trojan Horse" in the U.S. alliance system (Tiejun et al. 2016, 38-39). There is a wide gap between South Korean expectations and reality made by China in terms of Strategic Cooperative Partnership of two countries.

\section{SOUTH KOREAN EXPECTATION OF CHINESE SECURITY COOPERATION: SINKING OF THE CHEONAN AND BOMBARDMENT OF YEONPYEONG ISLAND}

The sinking of the South Korean navy warship Cheonan in March 2010, and the artillery bombardment of South Korea's Yeonpyeong Island in November the same year, by North Korea, occurred not long after the Strategic Cooperative Partnership agreement was signed by South Korea and China. It would be natural for South Korea to expect some sort of cooperation from China. The Chinese reaction, however, did not differ from its behavior that South Korea had witnessed before the agreement.

\section{The Sinking of the South Korean warship Cheonan}

The sinking of the Cheonan happened on March 26, 2010 at approximately 21:22, near Baeknyeong Island, when the warship, which was conducting a patrolling mission, received an attack by a North Korean torpedo (Civil-Military 
Joint Investigation Committee of Ministry of National Defense 2010, 34). As a result, 46 out of 104 crewmembers were killed in action. To determine the sinking's causes, the South Korean government organized a special investigation team, which consisted of 29 civilian experts from 12 nongovernmental organizations, 22 military experts, three members recommended by the National Assembly, and 24 international experts from the U.S., Australia, the United Kingdom, and Sweden. After spending about two months on the investigation, the team announced on May 20, 2010 that "the warship Cheonan was sunk because of the underwater explosion that was caused by a torpedo made by North Korea." The torpedo appeared to be fired from a small submarine that had infiltrated the sea around Baeknyeong Island (Civil-Military Joint Investigation Committee of Ministry of National Defense 2010, 26).

Based on this conclusion, President Lee Myung-bak announced sanctions, including a measure that North Korean vessels no longer could use South Korean seas on May 24, 2010. President Lee clarified that any further violent provocations against South Korea would trigger its right of self-defense. South Korea also requested the UNSC to issue another international sanction to prevent any recurrence of similar provocations (Chosun Ilbo 5/25/2010, A1). South Korea strengthened its combined military exercises with the U.S. and measures to comply with the U.S. Nonproliferation Security Initiative (PSI), which aims at searching for and confiscating any elements related to weapons of mass destruction at sea (Chosun Ilbo 5/25/2010, A3).

The responses from neighboring countries regarding the sinking of the warship were very similar to those during the Cold War. Three southern countries (Korea, the U.S., and Japan) and three northern countries (North Korea, China, and Russia) responded differently. The U.S. and Japan trusted the conclusion of the investigation, denounced North Korea, and demanded more sanctions against it. However, China and Russia, North Korea's Cold War allies, expressed their doubts about the investigation and supported North Korea. When the UNSC debated sanctions on North Korea, the U.S., and Japan stood strongly on South Korea's side, but China and Russia hindered the resolution by using their veto power. In the end, the UNSC had to settle for a Presidential Statement of the UNSC instead of a resolution and no sanction was agreed upon (Homepage of the South Korean Ministry of Foreign Affairs). China, in particular, displayed an uncooperative attitude toward South Korea. China emphasized a rational and restrained attitude and its principle that the problem should be resolved in a way to ensure the Korean Peninsula's peace and stability (Han 2010, 9-10). Chinese newspapers did not report the conclusion of the international investigation and advocated North Korean positions. China did not attempt to take any actions to prevent the repetition of a similar incident. It was natural for South Koreans to consider the partnership with China purely rhetorical (Han 2010, 11). 


\section{Bombardment of Yeonpyeong Island}

This incident occurred on November 23, 2010 between 14:34 and 15:41 hours. North Korean artillery, along with rocket launchers, attacked Yeonpyeong Island, which is definitely South Korean territory. Approximately 170 shells hit, causing the deaths of two marines and two civilians. The attack caused forest fires and damage to 133 buildings (including the total destruction of 33 buildings, the partial destruction of nine, and partial damage to 91) and electrical and communication facilities (Ministry of National Defense 2010, 267). South Korea retaliated with its $155 \mathrm{~mm}$ artillery systems deployed on Yeonpyeong Island, firing approximately 80 rounds. However, the shells were not effective because the South Korean military did not have clear observation of their targets (Ministry of National Defense 2010, 267). The incident was the largest artillery attack on South Korean soil since the end of the Korean War in 1953. Most television stations in South Korea and several international media broadcast the incident live.

The U.S. and Japan condemned North Korea in stronger terms than they did for the sinking of the Cheonan. A White House spokesman released a statement condemning North Korea. At 04:30 local time in Washington D.C., the U.S. called for a stop to belligerent actions and for North Korea to abide by the Armistice Agreement which was implemented in 1953 (Chosun Ilbo 11/24, 2010, A8). The Japanese Government held an urgent intelligence analysis meeting in the Prime Minister's office just after being informed of North Korea's provocation. Prime Minister Kan Naoto condemned North Korea for its unacceptable barbarous act. Even the Russian foreign minister criticized the North Korean bombardment (Chosun Ilbo 11/25/2010, A16).

China, however, took North Korea's side again. The statement issued by the Chinese Government did not differ from statements made after the Cheonan's sinking. The Chinese Government emphasized peace and stability on the Korean peninsula and requested that involved nations restrain themselves and be prudent. The Chinese Government claimed that North Korea attacked because South Korea had conducted a military drill on a disputed area of the sea. It declared that investigation could be necessary to decide the incident's actual cause, despite the fact that the bombardment had been broadcast live. China called both North Korean and South Korean ambassadors to ask for mutual restraint with regard to the incident (Chosun Ilbo 11/24/2010, A8). South Koreans had to admit that there was a significant perception gap between South Korea and China regarding their mutual relations.

\section{Analysis}

South Koreans seemed disappointed with China's attitude about the sinking 
of the Cheonan and the bombardment of Yeonpyeong Island. They had expected some changes in Chinese attitude, but the reality proved quite different. However, the partnership does not involve any responsibilities in nature. South Koreans seem to have expected too much to its partnership relations with China. China did not promise any security cooperation to South Korea. South Korea and China do not fulfill the necessary conditions for close security cooperation.

South Koreans came to realize that its previous understanding and expectation of South Korea-China relations were wrong after experiencing the Cheonan and Yeonpyeong Island incidents. They stopped mentioning the Strategic Cooperative Partnership with China. However, they could not abandon all previous wishful thinking regarding its relation with China.

\section{CHINESE EXPECTATIONS OF SOUTH KOREA'S YIELDING OF AUTONOMY: THE DEPLOYMENT OF THE U.S. THAAD}

\section{Background}

Curtis Scaparotti, then the commander of the USFK (U.S. Forces in Korea) and CFC (Republic of Korea-United States Combined Forces Command), mentioned at a breakfast meeting hosted by the Korean Institute for Defense Analysis that he had requested his government to deploy the THAAD system to South Korea on June 3, 2014 (Chosun Ilbo 6/04/2016, A1). South Korean progressives started to oppose the deployment by arguing that the THAAD system can intercept China's intercontinental ballistic missiles (ICBMs). They predicted that South Korea would become a scapegoat in the conflict between the U.S. and China, because China would act to destroy the system if deployed. However, South Korean conservatives defended the deployment, advocating that THAAD was essential for defense against the North Korean nuclear missile attack. Considerable controversy over THAAD spread throughout South Korean society.

The Chinese Government started to participate in the controversy over THAAD. Chinese President Xi Jinping was reported to have asked South Korean President Park Geunhye not to allow THAAD deployment at the South KoreaChina summit meeting in July 2014 (Yonhap News 8/26/2014). The Chinese ambassador to South Korea, Chu Guo Hong, opposed the deployment of THAAD at the South Korean National Assembly on November 26, 2014. The Chinese Minister of Defense, Chang Wan Quan, who attended the South Korea-China Defense Ministerial meeting held in Seoul, did the same on February 4, 2015. A higher official in the Chinese Ministry of Foreign Affairs, Liu Jin Chao, who visited South Korea to discuss other issues, strongly demanded that the South Korean Government not allow THAAD's deployment (Chosun Ilbo 3/17/2016).

The South Korean Government took China's opposition seriously. However, 
the North Korean nuclear threat was too serious for South Korea to relinquish THAAD, which was essential to protect the U.S. forces in Korea and the South Korean people as well. The South Korean Government decided to keep silent until the controversy settled down, by adopting its policy of "3 No's." It claimed that there had been no request from the U.S., no consultation, and no decision about THAAD's deployment (Yonhap News 3/11/2015).

The South Korean Government could not delay the deployment of THAAD any longer, as North Korea conducted its fourth nuclear test on January 6, 2016. A few National Assembly members from the opposition party demanded THAAD's deployment. The South Korean Government finally announced to start an official discussion with the U.S. on the deployment the next day, when North Korea tested its long-range ballistic missile on February 7, 2016. It reached the final decision to allow the deployment on July 8, 2016 and designated Seongju, in northern Gyeongsang Province as the deployment site.

Some South Korean people including the people in Seongju area started a strong opposition campaign by citing a possible health risk of electronic waves from the THAAD radar and Chinese opposition and threat of retaliation. The electronic waves turned out not to be true, but Chinese newspapers delivered harsh warnings against the deployment of THAAD. However, the South Korean Government and the U.S. forces in Korea deployed initial parts of THAAD battery on April 26, 2017 and they have been operational since then. After three years, the deployment still entails opposition from China and some elements of the South Korean population.

\section{Chinese Reactions}

The deployment of a defensive weapons system such as THAAD can hardly be a controversial issue. South Korea and the U.S. forces in Korea must strengthen their ballistic missile defense including THAAD deployment, because North Korea may have the capability to strike South Korea with nuclear missiles. THAAD can hardly intercept ICBMs or detect China's military activities, contrary to the Chinese claim due to its limited range. As long as China does not intend to attack South Korea or the U.S. bases in Korea with its missiles, THAAD cannot be any threat to Chinese security or military operations.

However, China strongly and consistently opposed the deployment THAAD to South Korea. It accused the deployment of undermining its "strategic interest" or "security interest" without elaborating how this undermining could occur. A few Chinese news media urged their government to consider war or military action, if THAAD were deployed in South Korea (Yonhap News 2/17/2016) and threatened that South Korea would be the first target, if military confrontation between the U.S. and China should occur (Chosun Ilbo 4/04/2016, A1; KOO 2015, 152). The 
Chinese Government dismissed requests of the U.S. and South Korean Governments to explain THAAD's exact capabilities. China made the deployment of THAAD, which was to protect the U.S. soldiers and South Korean people from a possible North Korean nuclear attack, a serious issue of conflict between South Korea and China and between the U.S. and China.

Chinese opposition grew more intense as the deployment was implemented. The Chinese Government even began retaliation against South Korea. It restricted its people from tourist visits to South Korea and made South Korean business in China difficult after the South Korean Government provided a golf course in Seongju for the THAAD battery in March 2017. It demanded the withdrawal of the THAAD battery when it was deployed to the golf course on April 26, 2017. South Korean businesses suffered from various unofficial retaliatory measures, which appeared to be caused by the Chinese Government's direction.

\section{Analysis}

Why China opposed THAAD deployment so vehemently remains unclear. Chinese newspapers conveyed a few reasons that THAAD could exceed South Korean requirements for defense from North Korean attack, could cause an arms race in Northeast Asia, could undermine China's strategic or security interest, or hurt the Korean peninsula's peace and stability, but these reasons do not make any sense. The THAAD system is purely defensive equipment by intercepting incoming missiles with the range of $200 \mathrm{~km}$. It cannot project any firepower to others and cannot change a military balance beyond tactical level. Therefore, China is suspected of opposing the deployment of THAAD to decouple South Korea from the South Korea-U.S. alliance. In fact, a Chinese Government official mentioned that it would not be any problem, if THAAD was made by Israel or Europe (Chosun Ilbo 3/30/2016, A3).

China may have asked for concessions of autonomy from South Korea using this THAAD issue based on old history, in which the Chosun Dynasty accepted patron-client relations with China. China may have wanted to ascertain what kind of choice South Korea would make between China and the U.S. through this THAAD issue. The controversy over the THAAD deployment seems to have elevated into a power game between China and the U.S (Koo 2015, 152). In fact, some South Koreans revealed their preference for China over the U.S. by opposing the deployment of THAAD just because China opposed the deployment.

Some South Koreans may have misunderstood the nature of the Strategic Cooperative Partnership with China. They wrongfully expected security cooperation from China since the partnership agreement was signed; thus, they felt disappointment with Chinese opposition to THAAD deployment. However, China did not think of any obligation to South Korea since signing the partnership agreement with South Korea. 
China appears to have been interested only in the benefits of the partnership, such as demanding South Korea give up some of its autonomy, but did not intend to fulfill their tacit obligations of the partnership, i.e., to try to help South Korea. There is a significant gap between South Korea's expectations and reality regarding the South Korean partnership relations with China.

\section{CONCLUSION}

South Koreans may be experiencing some fatigue over their alliance with the U.S. and that fatigue triggered their curiosity over improving relations with China. There has been a dominant trend in South Korea to strengthen its relations with China and to readjust its relations with the U.S. This trend led South Korea to sign the Strategic Cooperative Partnership with China and to expect security cooperation with China.

Contrary to South Koreans' expectations, however, the partnership with China did not yield the expected results, especially in the security sector. China advocated for North Korea when North Korea sank the South Korean navy warship Cheonan and bombarded South Korea's Yeonpyeong Island in 2010. China opposed the deployment of THAAD, which is a necessary defensive weapons system to defend the South Korean people from a possible North Korean nuclear missile attack. China acted just like it had done in the Cold War era, despite South Koreans' sincere desire to improve mutual relations between the two countries.

South Korea may have demanded more from China than it deserved. South Korea and China do not share a common threat or mutual interest. They are not in a situation to trust each other because South Korea is an ally of the U.S., which China considers its strategic competitor. Also, China is an ally of North Korea, which South Korea considers its enemy. The Strategic Cooperative Partnership between South Korea and China may well be mere rhetoric that promises nothing meaningful. There can be no window of opportunity for South Korea to obtain security cooperation from China, especially regarding North Korea.

Moreover, the South Korean partnership with China cannot replace or complement the alliance between South Korea and the U.S. A partnership relationship does not promise any security support in crisis or war. It cannot be used to reduce the threat from North Korea. The best course of action for South Korea could be making progress in cooperation with China through economic, social, and cultural exchanges and making the most of its alliance with the U.S. for its national security. China does not significantly appreciate South Korea's independent value, but must respect South Korea as long as South Korea remains allied with the U.S. If decoupling South Korea from the U.S. does seem possible, China may try to pressure South Korea to weaken its alliance with the U.S. 
However, if the decoupling seems impossible, China should respect South Korea in fear of confronting a stronger South Korea-U.S. alliance.

National security, of course, should be based on reality rather than on wishful thinking. Improved relations with China are important for South Korean economic prosperity. However, South Korea should not expect more than actually possible from China. If South Korea pursues more in its relations with China based on excessive expectation, it could weaken its alliance with the U.S. South Korea should not sacrifice its only and most reliable alliance partner, the U.S., for economic gains from China. Now is the right time for South Korea to end its experimental relation with China and return to the norm. For its neighbors, "it is not easy to live with China" (Womack 2010, 520).

South Korea could improve its relation with China if it does not have excessive expectations for China. South Korea and China cannot be close friends in crisis or war, but they could be good partners in the economic, social and cultural sectors. If South Korea does not demand that China provide security cooperation, then China would not compel South Korea to yield autonomy. Wishful thinking in international relations elevates expectations and ruins relations, leading to a disappointing reality.

\section{REFERENCES}

Altfeld, Michael F. 1984. "The Decision to Ally: A Theory and Test." The Western Political Quarterly 37(4): 523-544.

Civil-Military Joint Investigation Committee of Ministry of National Defense. 2010. Report of Joint Investigation Results: The Case of Cheonan Sinking (written in Korean). South Korean Ministry of National Defense.

Evans, Peter B., Harold K. Jacobson and Robert D. Putnam. 1993. Double-Edged Diplomacy. Berkeley: Univ. of California Press.

Han, Gwang-Hee. 2010. "The Deciding Factors of China's South Korea Policy: A Comparison between North Korean Nuclear Test and Cheonan Sinking" (written in Korean). EAI-CISS NASD 2010 Security Briefings 3.

Homepage of South Korean Ministry of Foreign Affairs. 2016, accessed May 3, 2017, http://www.mofa.go.kr/trade/hanbando/peace/data/index.jsp?menu= m 30_20_20\&tabmenu=t 2\&sp=/webmodule/htsboard/template/read/korboa rdread.jsp $\% 3$ FtypeID $=6 \% 26$ boardid $=10909 \% 26$ tableName $=$ TYPE DATAB OARD $\% 26$ seqno $=347343$

Hong, Yoon Sung, Shaoshi Zou, Sang Hyun Park and Rujun Yan. 2016. "Factors in China-Korea Relations: A Survey of College Students in China and Korea." International Journal of Humanities \& Social Science Studies (IJHSSS) 3(1): 288-296.

Kim, Jiyoon. 2014. South Korean Attitudes on China. Asan Public Report (The 


\section{Asan Institute).}

Kim, Tae-Ho. 2013. "Sino-ROK Relations at 21: From Qiutongcunyi to Yizhongqiutong" (written in Korean). Geon-Ryak-Yeon-Gu 60: 5-37.

Koo, Bon-Hak. 2015. "Balancing Relations with the U.S. and China" (written in Korean). Sin- $A-S e-A$ 22(4): 135-161.

Ministry of National Defense. 2010. 2010 Defense White Paper (written in Korean). Seoul: MND.

Morrow, James D. 1991. "An Alternative to the Capabilities Aggregation Model of Alliances.” American Journal of Political Science 35(4): 904-933.

NATO. "Partnership for Peace Programme," accessed May 5, 2016, http://www. nato.int/cps/en/natohq/topics_50349.htm?selectedLocale=en

Osgood, Robert E. 1968. Alliance and American Foreign Policy. Baltimore: The Johns Hopkins Press.

Park, Hwee-Rhak. 2016. "An Impact of the Controversies over the THAAD to the South Korea-U.S. Alliance and the South Korea-China Relation: Application of Autonomy-Security Trade Model" (written in Korean). Guk-Je-GwanGye-Yeon-Gu 21(1): 33-63.

Rosenau, James N. ed. 1969. Linkage Politics. New York: The Free Press.

Seo, Jeong-Kyung. 2014. "Where does ROK-China Relations Stand?: Xi's Visit to Korea" (written in Korean). Jung-Guk-Hak-Yeon-Gu 70: 259-279.

Snyder, Glenn H. 1984. "The Security Dilemma in Alliance Politics." World Politics 36(4): 461-495.

Snyder, Scott. 2016. "A Complex China-ROK Partnership.” Comparative Connections (January): 101-111.

Tiejun, Yu et al. 2016. Chinese Perspectives towards the Korean Peninsula. Stimson. Walt, Stephen M. 1997. "Why Alliances Endure or Collapse?" Survival: Global Politics and Strategy 39(1): 156-179.

Zhongping, Feng and Jing, Huang. 2014. "China's Strategic Partnership Diplomacy: Engaging with a Changing World," European Strategic Partnership Observatory Working Paper 8 (June), accessed October 16, 2016, http://fride.org/descarga/ WP8 China strategic partnership_diplomacy.pdf 